\title{
RETRAKCIJA: UTICAJ AUTORSTVA NA PROCENU DUBOKOUMNOSTI PSEUDODUBOKOUMNIH VERBALIZAMA: KO IZGOVARA I KO VERUJE U BESMISLICE? (2019, VOL. 12, BR. 2, STR. 183-204)
}

\section{Uredništvo}

Uredništvo časopisa Primenjena psihologija ovim putem obaveštava naučnu i stručnu javnost o povlačenju rada „Uticaj autorstva na procenu pseudodubokoumnih verbalizama: ko izgovara i ko veruje u besmislice?" autorki Sandre Ilić i Kaje Damnjanović, koji je objavljen u prošlom broju (2019, vol. 12, br. 2, str. 183-204). Rad se povlači na inicijativu autorki, a uz saglasnost Uredništva, jer su u tekstu intervencijom Uredništva načinjene izmene za koje nije dobijena saglasnost autorki, te čije ispravke nije bilo moguće objaviti u Erratum-u. Uredništvo nije odobrilo Erratum zbog jedinstvenog stava da je uklonjeni citat sporan, te da Uredništvo i Filozofski fakultet u Novom Sadu kao izdavač mogu snositi pravne posledice zbog eventualne povrede časti i ugleda citiranog autora. Uredništvo se u donošenju ove odluke rukovodilo Etičkim kodeksom o objavljivanju radova i sprečavanju zloupotrebe podataka, koji je donet 13.5.2013. godine na sednici Saveta Filozofskog fakulteta u Novom Sadu, a u kojem se navodi da se urednik mora voditi politikom uređivačkog odbora časopisa i delati u skladu sa važećim pravnim okvirima koji se tiču javnih optužbi.

Opozvani rad se nalazi na web-lokaciji: http://primenjena.psihologija.ff.uns. ac.rs/index.php/pp/article/view/2190/2142 